\title{
Dual Mode Module as New Innovation in Learning Chemistry: Project Based Learning Oriented
}

\author{
https://doi.org/10.3991/ijim.v15i18.24549 \\ Wimbi Apriwanda N, Mangai Solomon Mahanan, Nor Hasniza Ibrahim ${ }^{(凶)}$, \\ Johari Surif, Sharifah Osman, Muhammad Abd Hadi Bunyamin \\ Universiti Teknologi Malaysia, Johor Bahru, Malaysia \\ p-norhaniza@utm.my
}

\begin{abstract}
Chemical representation is differentiator of chemistry to branches of science. This skill must be emphasized in learning chemistry to make students mastering chemistry deeply. Instead of chemical representation, science process skills are also crucial skill in learning chemistry. Unfortunately, the preliminary study found that this COVID19 situation inhibits teachers to encourage these skills because of the limitation learning media had. Thus, it needed learning media that could be used when online learning, and face-to-face learning, and also emphasized chemical representation, and science process skills. This study aimed to develop valid module integrated chemical representation and science process skills, and can be used in face-to-face learning and online learning (dual mode module) and to investigate teachers' response about module. The research design used was ADDIE, data collected by using online validation form that was given to 6 validators. To investigate chemistry teachers' responses to module, online questionnaire given to teachers and it was further analyzed using percentage and compare to criteria of validity and criteria of response user. The result showed that module is valid with suitability content $(90.7 \%)$, potential effectiveness (92\%), and overall satisfaction (92.5\%). The overall chemistry teachers' responses showed that this module was very good criteria $(92.36 \%)$. Hopefully dual mode module would be used in learning chemistry in many situations, and further could improve students' chemical representation and science process skills.
\end{abstract}

Keywords - project based learning, chemistry, science process skills, chemical representation, module

\section{Introduction}

\subsection{Background}

Chemistry is one branch of science that is related to substances which included composition, structure, properties, changes, energy, and dynamics [1]. The difference of chemistry with other sciences is the representation levels also known as chemical representation. Chemical representation includes microscopic, macroscopic, and symbolic [2]. The three aspects are related to each other like a triangle in which chemical 
phenomena can also be seen through these levels. Symbolic is the term of chemical phenomena in the form of things such as diagrams, pictures, formulae. In terms of macroscopic level, the chemical phenomena are shown through the experiment or in other words it includes the things that can be clearly seen with naked eyes. Finally, in terms of microscopic, it shows phenomena that cannot be observed by naked eyes, it needs tools to see what happens in terms of particles such as the interaction between particles, the chemical bond, and to know the movement of particles. The lack of proper understanding of all chemical representations often makes students feel confused and sees it as a difficult task which makes them assumed that chemistry is difficult [3]. The assumption is in line with [4] which stated that chemistry is a difficult subject caused by triangle representations in chemistry that must be mastered. However, the integration of microscopic, macroscopic, and symbolic representations causes difficulty to teachers in conducting learning and teaching chemistry because the teachers also need to fully visualize and conceptualize it.

In order to identify problems that existed in chemistry education, preliminary study was carried out by interviewing experienced chemistry teachers after which, we proceeded with a need analysis. The result of preliminary study further was tried to find out the solution, in this case, the problem found was the students have difficulty to master chemistry subject because of the chemical of representation made students confused and the teachers also experienced challenges in visualizing and conceptualizing the chemical representation during learning and teaching chemistry. Besides of that problems, the teachers have difficulty to conduct experiments, when it conducted faceto-face, they only gave the worksheet and students must follow the instructions, and for online learning, the teachers only send the video contained how to conduct the experiment. Indeed, those will be problems because the engagement of students is not considered, in other words, they only do an experiment like cooking recipes-oriented, and in online learning, the students could not train their psychomotor due to the science process skills of students never be encouraged. Also, the use of media in learning and teaching chemistry is still limited namely the teachers only use PowerPoint, and video and this COVID pandemic made the teachers must to do more effort.

In chemistry, rate of chemical reaction is a topic that requires students' active participation in order to observe changes of reactants or products with respect to time. The changes in some cases can be observed at the macroscopic level. Rate of reaction can somewhat be associated with kinetic molecular theory. This suggests for devising various practical-based learning experience [6] that can aid constructive learning amongst students' [7]. [5] shows that the kinetic molecular theory, which states that all matter is composed of tiny particles that are constantly in motion, provides a basis for understanding the invisible molecular events underlying natural phenomena as well as for explaining observable aspects of these same phenomena. However, understanding the reaction in terms of molecular interactions taking place at the sub-microscopic level may be challenging [8]. [9] also found that many students assumed that this topic involves abstract (microscopic) and need the calculation (symbolic). Therefore, the engagement of students to use their imagination and metacognition is crucial to understanding and finding solutions to difficulties in learning chemistry at all knowledge levels [8]. 
Therefore, based on the problem that existed and the urgency to chemical representation and science process skills in learning chemistry, it can be concluded that the problems existed due to the limitation of chemistry learning media either using in faceto-face learning or online learning which can cover chemical representation and science process skills. So that, it needs media integrated chemical representation and science process skills. According to [10], the science process skills have positive relationships with multiple representations, and to make students mastering chemical representation, the students' involvement is important (students-centered). As crucial skills in science, the skills must be encouraged in learning chemistry, it is supported by [11] who found that students' science process skills have a strong relationship with motivations so it also can improve students' motivation in learning chemistry. According to [3], the science process skills can be improved by making students active in learning such as providing them to do projects [12].

Project-Based Learning (PBL) is a form of teaching in which learners acquire knowledge through active involvement in real-world and personally relevant projects [3]. According to [13], Project-based learning (PBL) is a student-centered learning approach that allows learners to learn through authentic real-world activities or projects. The PBL approach in science fields has provided for students to establish a link between their classroom understanding and real-world experience [14]. Meta-analysis carried out by [12] revealed that the effect of PBL in science education was significantly higher than the traditional learning, though the effect size varied across subject areas. PBL is shown to improve students' psychomotor skills. This was described by findings of [15], which shows that mechanical response, complex response, adaptation and origination were high after engaging students in PBL activity. In terms of learning media, [16] developed a module and found that the module assisted PBL improve students' learning outcomes. Therefore, this module of learning is suitable for these problems because according to [17], learning chemistry outcomes have a relationship with science process skills.

This amongst results of several studies that underpinned the importance of PBL informs our desire to develop a module that applies PBL for learning rate of chemical reaction that can be applied in face-to-face learning and online learning (dual mode module). This is believed to contribute towards engaging students to learn via online with the recent increasing shift to online learning [18].

\section{$1.2 \quad$ Literature review}

Chemistry is sometimes perceived as a challenging subject, an experience that often leads to students discontinuing to study the subject [19], several studies have associated students' difficulty in chemistry, to factors such as lack of visualization of the submicroscopic level, establishment of connection between macroscopic, submicroscopic and symbolic representations and Formation of mental model of the chemical ontology [20] - [22]. However, other factors such as students' engagement also plays a role in how this difficulty is perceived. [23] highlights that, engaging students through project-based learning led to improvement in their learning outcomes. The engagement could be teacher to learner or learner to learner; students working on small groups 
better engage them thereby increasing their satisfaction, motivation and academic performance [24]. Chemistry has been recognized based on its multiple representations which normally involve the three knowledge levels; these levels include: macroscopic, sub-microscopic and symbolic representation [2]. The extensive studies carried out in the field of chemistry education in a bit to find ways of enhancing its learnability by higher and lower school beginners in chemistry have associated some learning difficulties with students' inability to articulate and establish connections between these knowledge levels [25]. Students' difficulty in learning chemistry has been associated with lack of understanding the ontology of chemical substances at the sub microscopic level and relating it with the symbolic representation which often leads them to developing mental models of only the macroscopic observable substances [26] - [29]. Despite that, students may easily observe macroscopic substance, it may make little sense from a chemical perspective, if they cannot reason out the molecular entities or phenomena existing at the sub-microscopic level that constitute the macroscopic substance [30].

Science Process Skills (SPS) are a set of abilities used in scientific learning where students develop more of such abilities by engaging in active autonomous learning [31]. In science learning, the experimental method conducted to acquire understanding and scientific truth through study is referred to as science process skills [11]. The science process skills constitute two forms of skills which include integrated and basic skills; the integrated skills involve hypothesizing, experimenting, interpreting, controlling variables and operational definitions whereas, basic skills include observing, classifying, communicating, using time and space relation, measuring and using number, predicting, and inferring [32].

Project Based Learning (PBL) is a form of teaching in which learners acquire knowledge through active involvement in real-world and personally relevant projects [3]. According to [13], Project-based learning (PBL) is a student-centered learning approach that allows learners to learn through authentic real-world activities or projects. [33] also defined Project-based learning (PBL) is an inquiry-based learning model in which teachers serve to scaffold and lead students through an extended investigation phase that requires working together to accomplish a project. The emphasis placed on project-based learning has it that several studies have attempted investigating the impact of this learning approach to students' learning outcomes as compared with the traditional learning approach. For instance, [34], recently found that Project-based learning has shown significant improvement in the cognitive test score of students who learned through the PBL approach. Furthermore, student's work performance and scientific abilities were high which gave the teachers and students some courage to positively respond to the implementation of the learning approach.

Several studies have seemingly acknowledged improvement of students' science process skills through inquiry-based learning. That notwithstanding does not negate the fact that PBL can also be a viable pedagogy for enhancing the SPS. [3] reveals from their finding that SPS can be improved through PBL. They noted that students are often not given the opportunity to engage in learning activities that would improve 
their SPS. Though it is stated clearly in the aims, it may not guarantee that students are actively engaged in learning activities that would ultimately improve their SPS which is in concomitant with [3]. Project-based learning has been found to be a valid learning model for improving SPS [35]. A study by [11] shows a strong relationship between motivation and SPS. Students who engage in learning through PBL showed more improvement in science process skills than those who learned through a conventional learning approach [3].

Engaging students through student-centered pedagogies such as Project-based learning which provides students with opportunities to carry out projects within small groups may likely be beneficial to their deep understanding of the chemical phenomenon involved in the learning process. [12] buttress the fact that when PBL is incorporated with learning materials that carries the three chemical representations, students' understanding might be more deepened and may result in realization of more learning outcomes. Furthermore, [29] highlighted the fact that students' understanding of chemical knowledge in all the three representation levels can be improved if they are granted the opportunity to communicate their own understanding through practice, and so, one of such ways might be through PBL. According to [20], constructing meaningful chemical knowledge would be more realistic if learning experiences that clearly communicate all the three representations to students are given much attention right at primary and secondary school level.

\section{Research objectives}

Based on these existing issues, the objectives of this study are 1) to develop valid module integrated chemical representation and science process skills, and can be used in face-to-face learning and online learning (dual mode module), 2) to investigate teachers' responses about module.

\section{$3 \quad$ Research methodology}

\subsection{Research design}

This study was type of Research and Development (R\&D) which used ADDIE Model as procedure followed. According to [36], ADDIE model is one of the most common models used in the instructional design field a guide to producing an effective design. There are 5 phases in ADDIE (Analysis, Design, Development, Implementation, Evaluation). The detail explanation of how to develop this module can be seen by Table 1. 
Table 1. Detail information of activities in ADDIE

\begin{tabular}{|c|c|c|}
\hline Steps & Activities & The Explanation \\
\hline Analysis & $\begin{array}{l}\text { Need Analysis } \\
\text { Content Analysis }\end{array}$ & $\begin{array}{l}\text { The preliminary study was conducted by using } \\
\text { interview technique among chemistry teachers to } \\
\text { identify problem existed in learning chemistry and } \\
\text { tried to help the teachers to solve the problem by } \\
\text { analyzing the need. Content analysis was used to see } \\
\text { the appropriate content that will be developed. Once } \\
\text { the problem was identified, it was found that the } \\
\text { teachers need learning media such as module that } \\
\text { can be used online or offline (face-to-face). }\end{array}$ \\
\hline Design & $\begin{array}{l}\text { Determine suitable model of } \\
\text { learning } \\
\text { Design activity } \\
\text { Design template module }\end{array}$ & $\begin{array}{l}\text { Project- based learning was suitable model of } \\
\text { learning because it can encourage learning chemistry } \\
\text { to be students-centered. The template of module also } \\
\text { was designed to make students interested during } \\
\text { learning chemistry. }\end{array}$ \\
\hline Development & $\begin{array}{l}\text { Develop module } \\
\text { Validation process }\end{array}$ & $\begin{array}{l}\text { Module was developed as solution to overcome } \\
\text { the problem identified namely module that can be } \\
\text { used in online learning and face-to-face learning } \\
\text { which integrated science process skills and chemical } \\
\text { representation. } \\
\text { The module developed was validated by } 6 \text { validators } \\
\text { expert. }\end{array}$ \\
\hline Implementation & $\begin{array}{l}\text { Give to chemistry teachers } \\
\text { to see their response }\end{array}$ & $\begin{array}{l}\text { The valid module was given to } 27 \text { chemistry } \\
\text { teachers to see their response. }\end{array}$ \\
\hline Evaluation & Formative evaluation & $\begin{array}{l}\text { Self-evaluation } \\
\text { Evaluation by expert (validators \& lecturers) }\end{array}$ \\
\hline
\end{tabular}

In this study, data was collected by giving online validation form as instrument of validation to 6 experts using Likert scale with 4 options. There were 3 aspects which have been assessed by validators such suitability to the content, potential effectiveness, and overall satisfaction. After validation, the module was given to 27 chemistry teachers to investigate the response of teachers about the module. To determine the respondents, the purposive sampling was used in this study. [37] stated that purposive sampling is method which the selection of sample depends on the judgement of the researchers. The selection of respondent was based on the willingness of chemistry teachers to give the feedback by reading module. Furthermore, data collected was analyzed using percentage by calculation of percentage of validation score and teachers' response. The result of percentage was compared to validation of criteria according to [38] as shown by Table 2 .

Table 2. Validation of criteria

\begin{tabular}{|c|l|}
\hline Percentage & \multicolumn{1}{c|}{ The Validity Criteria } \\
\hline $75.00-100$ & Valid \\
\hline $50.00-74.99$ & Quite Valid \\
\hline $25.00-49.99$ & Less Valid \\
\hline $0.00-24.99$ & Invalid \\
\hline
\end{tabular}


To investigate teachers' response, the teachers read the module and assessed the module based on instrument provided. The result was obtained in percentage and compared to criteria response of users according to [38] as shown by Table 3.

Table 3. Criteria response of users

\begin{tabular}{|c|l|}
\hline Percentage & \multicolumn{1}{c|}{ Criteria Response of Users } \\
\hline $75.00-100$ & Very Good \\
\hline $50.00-74.99$ & Good \\
\hline $25.00-49.99$ & Less Good \\
\hline $0.00-24.99$ & Not Good \\
\hline
\end{tabular}

\subsection{Dual mode module}

Based on the preliminary of study and the result of analysis, and design, thus, it needs module that can encourage chemical representation and science process skills that can be used in face-to-face learning or online learning. In this module, it provides two lesson plans oriented Project based learning which one lesson plan for faceto-face learning and one lesson plan for online learning. The lesson plan was elaborated through module. The main features in this module are the module provide activities that can encourage science process skills and chemical representations and interactive explanation about rate of reaction. In addition, all activities were designed and developed interestingly that can make students being attractive to learning chemistry. The cover, and the explanation of these features can be seen through Figure 1.
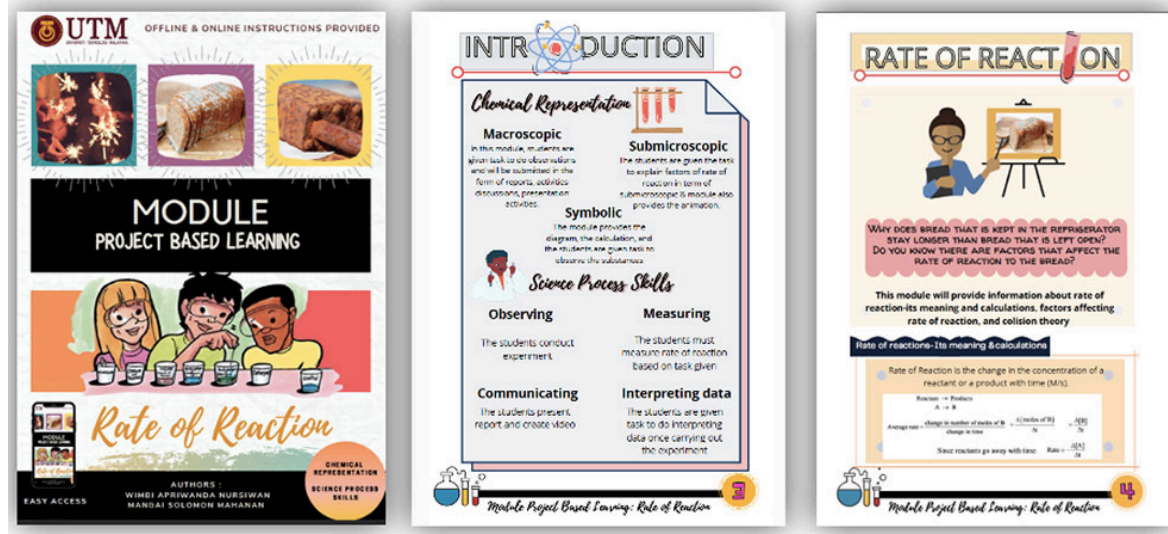

Fig. 1. Cover \& the main features in dual mode module

The following Table 4 shows the explanation of chemical representation and science process skills in the module. 
Table 4. The explanation of chemical representation and science process skills in the module

\begin{tabular}{|c|c|c|c|}
\hline $\begin{array}{c}\text { Chemical } \\
\text { Representation }\end{array}$ & Activities & $\begin{array}{l}\text { Science Process } \\
\text { Skills }\end{array}$ & Activities \\
\hline \multirow[t]{2}{*}{ Macroscopic } & \multirow{2}{*}{$\begin{array}{l}\text { In this module, students are } \\
\text { given task to do observations } \\
\text { and will be submitted in the } \\
\text { form of reports, activities } \\
\text { discussions, presentation } \\
\text { activities. }\end{array}$} & Observing & $\begin{array}{l}\text { The students conduct } \\
\text { experiment }\end{array}$ \\
\hline & & Measuring & $\begin{array}{l}\text { The students must measure } \\
\text { rate of reaction based on } \\
\text { task given }\end{array}$ \\
\hline Submicroscopic & $\begin{array}{l}\text { The students are given the } \\
\text { task to explain factors of } \\
\text { rate of reaction in term of } \\
\text { submicroscopic \& module also } \\
\text { provides the animation }\end{array}$ & Communicating & $\begin{array}{l}\text { The students present report } \\
\text { and create video }\end{array}$ \\
\hline Symbolic & $\begin{array}{l}\text { The module provides the } \\
\text { diagram, the calculation, and } \\
\text { the students are given task to } \\
\text { observe the substances }\end{array}$ & Interpreting data & $\begin{array}{l}\text { The students are given } \\
\text { task to do interpreting } \\
\text { data once carrying out the } \\
\text { experiment }\end{array}$ \\
\hline
\end{tabular}

The activities in module ask students for doing project. For example, in face-to-face learning, the students will be Rate of Reaction Expert, they must conduct one experiment related to factors of effecting rate of reaction, the instructions will be provided in the boxes, so the students must select randomly the box. The students will conduct the experiment based on instruction and explain the concept of factors of effecting rate of reaction that involved submicroscopic level. The Figure 2 shows the activities in faceto-face learning.

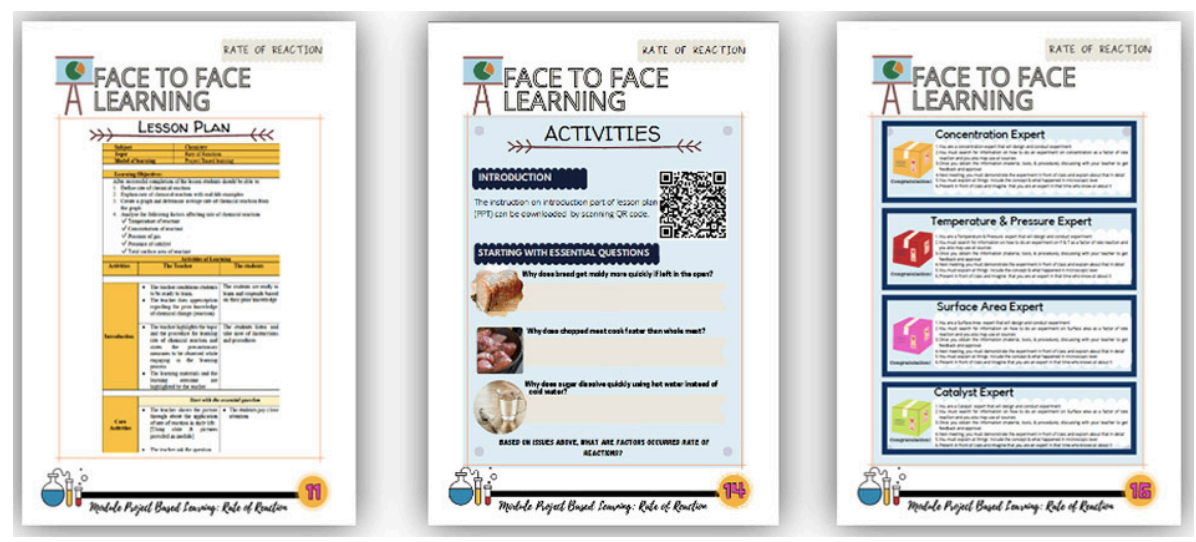

Fig. 2. The face-to-face learning in module

For online learning, the project given is different. The students must create the video and do self-experiment about factors effecting rate of reaction in their home by using simple material and tools. Figure 3 shows the activities in online learning. 

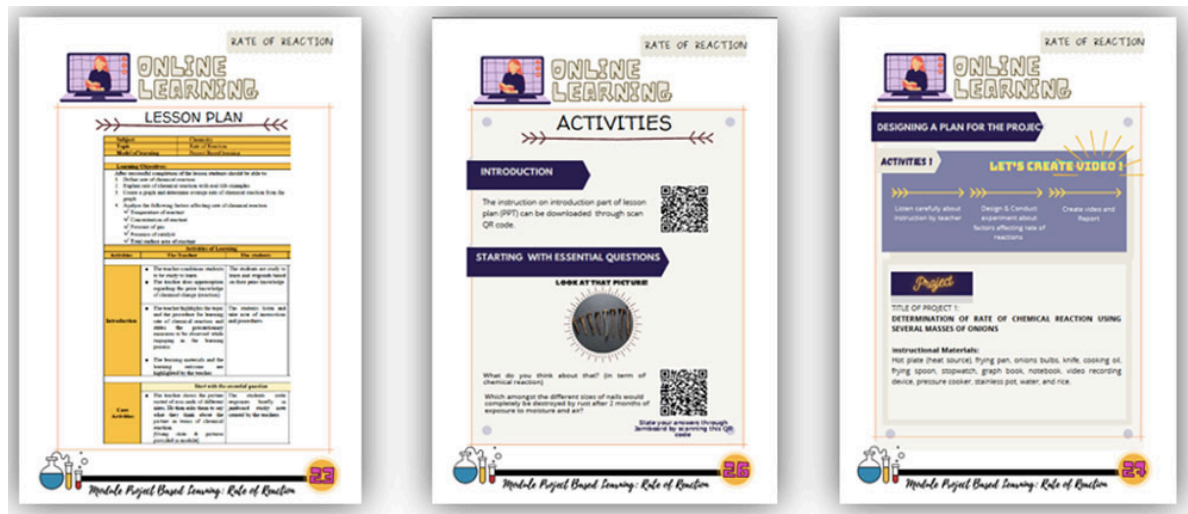

Fig. 3. The online learning in module

\section{$4 \quad$ Results \& discussion}

\subsection{Validity}

The module is learning media that can be used by students independently with or without teacher guidance and by using module students are able to arrange their learning, also, it will help teachers to assess the level of content that must be mastered by students [39]. In addition, it is also useful for student learning more effectively, and it also help student more concentrate if they are interested in a particular subject [40].

In this study, module was a solution to help teachers support students' chemical representation knowledge, and science process skills. According to [41], in order to obtain the module that is suitable and easy to be read by reader, validity is important to be carried out. In this study, the module was assessed based on suitability of content, potential effectiveness, and overall satisfaction.

Suitability of content, module which can be used in learning is a module which has been content valid, or in another word the content of module is correct [42]. Table 5 shows the result of suitability of content aspect validity.

Table 5. The result of suitability of content aspect validity of module

\begin{tabular}{|l|c|l|}
\hline \multicolumn{1}{|c|}{ Suitability of Content Aspect Items } & $\begin{array}{c}\text { Average of Percentage from } \\
\text { Validators' Assessment }\end{array}$ & \multicolumn{1}{c|}{$\begin{array}{c}\text { Validity } \\
\text { Criteria }\end{array}$} \\
\hline $\begin{array}{l}\text { The composition of the learning objectives in } \\
\text { the module is clear }\end{array}$ & $95.8 \%$ & Valid \\
\hline $\begin{array}{l}\text { The composition of the objectives of the module } \\
\text { can be achieved based on the teaching activities } \\
\text { and the strategies used }\end{array}$ & $87.5 \%$ & Valid \\
\hline $\begin{array}{l}\text { Learning objectives are defined for each activity } \\
\text { according to the activities and assessments } \\
\text { suggested }\end{array}$ & $95.8 \%$ & Valid \\
\hline
\end{tabular}

(Continued) 
Table 5. The result of suitability of content aspect validity of module (continued)

\begin{tabular}{|l|c|l|}
\hline \multicolumn{1}{|c|}{ Suitability of Content Aspect Items } & $\begin{array}{c}\text { Average of Percentage from } \\
\text { Validators' Assessment }\end{array}$ & \multicolumn{1}{|c|}{$\begin{array}{c}\text { Validity } \\
\text { Criteria }\end{array}$} \\
\hline $\begin{array}{l}\text { Teaching objectives can achieve Module } \\
\text { objectives }\end{array}$ & $87.5 \%$ & Valid \\
\hline $\begin{array}{l}\text { Teaching objectives are expressed in } \\
\text { measurable behavior }\end{array}$ & $79.2 \%$ & Valid \\
\hline $\begin{array}{l}\text { Teaching objectives that are stated to lead } \\
\text { to the achievement of learning outcomes }\end{array}$ & $91.7 \%$ & Valid \\
\hline $\begin{array}{l}\text { Module content is able to meet the stated } \\
\text { learning objectives }\end{array}$ & $91.7 \%$ & Valid \\
\hline $\begin{array}{l}\text { The module content is complete in terms } \\
\text { of evaluation }\end{array}$ & $95.8 \%$ & Valid \\
\hline
\end{tabular}

Based on Table 5, it can be concluded that module has been content valid. For example, based on validators' judgement the composition of the learning objectives in the module is clear, learning objectives are defined for each activity according to the activities and assessments suggested, and the module content is complete in terms of evaluation that have the highest percentage (95.8\%). Besides, the validators also assessed that teaching objectives that are stated to lead to the achievement of learning outcomes, module content is able to meet the stated learning objectives and it is complete in terms of teaching steps with percentage $91.7 \%$.

Other components also found valid such as the composition of the objectives of the module can be achieved based on the teaching activities and the strategies used, teaching objectives can achieve module objectives, and teaching objectives are expressed in measurable behavior with percentage $87.5 \%, 87,5 \%$ and 79.2 respectively. Therefore, if compared to validity criteria according to [38], all components in module are valid in form of content.

Potential effectiveness. Table 6 shows the result of potential effectiveness aspect validity of module.

Table 6. The result of potential effectiveness aspect validity of module

\begin{tabular}{|l|c|l|}
\hline \multicolumn{1}{|c|}{ Potential Effectiveness Aspect Items } & $\begin{array}{c}\text { Average of Percentage from } \\
\text { Validators' Assessment }\end{array}$ & \multicolumn{1}{c|}{$\begin{array}{c}\text { Validity } \\
\text { Criteria }\end{array}$} \\
\hline $\begin{array}{l}\text { The learning strategy in each activity } \\
\text { is in line with the students' level of } \\
\text { thinking }\end{array}$ & $91.7 \%$ & Valid \\
\hline $\begin{array}{l}\text { The techniques used in the module } \\
\text { can be applied effectively }\end{array}$ & $95.8 \%$ & Valid \\
\hline $\begin{array}{l}\text { The teaching strategy applied is in } \\
\text { accordance with the syntax in Project } \\
\text { Based Learning }\end{array}$ & $95.8 \%$ & Valid \\
\hline $\begin{array}{l}\text { The learning model applied to the } \\
\text { module challenges students to think }\end{array}$ & $91.7 \%$ & Valid \\
\hline
\end{tabular}


Table 6. The result of potential effectiveness aspect validity of module (continued)

\begin{tabular}{|c|c|c|}
\hline Potential Effectiveness Aspect Items & $\begin{array}{l}\text { Average of Percentage from } \\
\text { Validators' Assessment }\end{array}$ & $\begin{array}{l}\text { Validity } \\
\text { Criteria }\end{array}$ \\
\hline $\begin{array}{l}\text { Activities proposed use appropriate } \\
\text { techniques to stimulate student } \\
\text { activity in participating in Chemistry } \\
\text { classes }\end{array}$ & $91.7 \%$ & Valid \\
\hline $\begin{array}{l}\text { The scope and order of topics in the module } \\
\text { correspond to the developmental needs of } \\
\text { students }\end{array}$ & $95.8 \%$ & Valid \\
\hline $\begin{array}{l}\text { The proposed activities are in line with the } \\
\text { material presented }\end{array}$ & $95.8 \%$ & Valid \\
\hline $\begin{array}{l}\text { The content presented in the module can be } \\
\text { used by all parties in teaching chemistry }\end{array}$ & $91.7 \%$ & Valid \\
\hline $\begin{array}{l}\text { The module content is suitable for use in } \\
\text { different contexts such as at home, school, } \\
\text { and others }\end{array}$ & $87.5 \%$ & Valid \\
\hline $\begin{array}{l}\text { Each topic in the module is arranged } \\
\text { logically and coherently in a learning } \\
\text { sequence }\end{array}$ & $87.5 \%$ & Valid \\
\hline $\begin{array}{l}\text { The learning media provided are in } \\
\text { accordance with the lesson plan provided } \\
\text { in the module }\end{array}$ & $83.3 \%$ & Valid \\
\hline $\begin{array}{l}\text { The module provides an assessment in } \\
\text { accordance with the learning objectives } \\
\text { in the lesson plan }\end{array}$ & $83.3 \%$ & Valid \\
\hline $\begin{array}{l}\text { The assessment given can measure the level } \\
\text { of achievement of teaching goals }\end{array}$ & $91.7 \%$ & Valid \\
\hline $\begin{array}{l}\text { The assessment components are in } \\
\text { accordance with the module content }\end{array}$ & $91.7 \%$ & Valid \\
\hline
\end{tabular}

Based on Table 6, the result from validators assessed module was valid in form strategy used such as the learning strategy in each activity is in line with the students' level of thinking $(91.7 \%)$, the techniques used in the module can be applied effectively (95.8\%), the teaching strategy applied is in accordance with the syntax in Project Based Learning (95.8\%), and the learning model applied to the module challenges students to think (91.7\%). Also, activities proposed use appropriate techniques to stimulate student activity in participating in Chemistry classes (91.7\%), the scope and order of topics in the module correspond to the developmental needs of students $(95.8 \%)$, the proposed activities are in line with the material presented $(95.8 \%)$, and the content presented in the module can be used by all parties in teaching chemistry $(91.7 \%)$.

In form of arrangement, presentation, and the use module, it was also valid with $91.7 \%$ from validators' assessment assumed that the content presented in the module can be used by all parties in teaching chemistry, the module content is suitable for use in different contexts such as at home, school, and others, each topic in the module is arranged logically and coherently in a learning sequence as much as $87.5 \%$ respectively, and the learning media provided are in accordance with the lesson plan provided 
in the module (83.3\%). In form of assessment provided in module, $83.3 \%$ of the average of percentage from validators' assessment showed that module provides an assessment in accordance with the learning objectives in the lesson plan, and $91.7 \%$ from validators' assessment showed that assessment given in module can measure the level of achievement of teaching goals, and the assessment components are in accordance with the module content.

All the result of module assessment based on potential effectiveness is lined with [40] that stated that beside of content, module that was developed must consider effectiveness of students' need, suitable strategy, students' participation, and assessment. The module also must relate to students' potential, knowledge transfer, and skills from context to the reality [40].

Overall satisfaction. the overall satisfaction of module's validation can be seen through Table 7 .

Table 7. The result of overall satisfaction aspect validity of module

\begin{tabular}{|l|c|l|}
\hline \multicolumn{1}{|c|}{ Overall Satisfaction Aspect Validity } & $\begin{array}{c}\text { Average of Percentage from } \\
\text { Validators' Assessment }\end{array}$ & $\begin{array}{c}\text { Validity } \\
\text { Criteria }\end{array}$ \\
\hline $\begin{array}{l}\text { Activities in the module support students' } \\
\text { science skills in learning Chemistry }\end{array}$ & $91.7 \%$ & Valid \\
\hline $\begin{array}{l}\text { The module provides multiple representations } \\
\text { (microscopic, symbolic, and macroscopic) in } \\
\text { learning Chemistry clearly }\end{array}$ & $95.8 \%$ & Valid \\
\hline $\begin{array}{l}\text { Module makes students directly involved in } \\
\text { learning }\end{array}$ & $95.8 \%$ & Valid \\
\hline $\begin{array}{l}\text { The activities presented in the module are in } \\
\text { accordance with the characteristics of Project } \\
\text { Based Learning }\end{array}$ & $91.7 \%$ & Valid \\
\hline $\begin{array}{l}\text { Overall, the module can help teachers support } \\
\text { science process skills and introduce multiple } \\
\text { representations of chemistry among students }\end{array}$ & $87.5 \%$ & Valid \\
\hline
\end{tabular}

The result of validators' assessment shows that activities in the module support students' science skills in learning chemistry $(91.7 \%)$, the module provides multiple representations (microscopic, symbolic, and macroscopic) in learning Chemistry clearly (95.8\%), module makes students directly involved in learning (95.8\%), the activities presented in the module are in accordance with the characteristics of Project Based Learning (91.7\%), and overall, the module can help teachers support science process skills and introduce multiple representations of chemistry among students $(87.5 \%)$. Therefore, this module can be a solution to teachers in supporting science process skills and chemical representation in learning rate of chemical reaction. The summarize of result module validity can be seen in Table 8 and Figure 4. 
Table 8. The summarize of result module validity

\begin{tabular}{|l|c|c|c|l|}
\hline \multirow{2}{*}{ Validator } & \multicolumn{3}{|c|}{ Percentage of Aspects } & \multirow{2}{*}{$\begin{array}{c}\text { Validity } \\
\text { Criteria }\end{array}$} \\
\cline { 2 - 5 } & Content & $\begin{array}{c}\text { Potential } \\
\text { Effectiveness }\end{array}$ & $\begin{array}{c}\text { Overall } \\
\text { Satisfaction }\end{array}$ & $100 \%$ \\
\hline Validator 1 & $97.2 \%$ & $98.2 \%$ & $90 \%$ & Valid \\
\hline Validator 2 & $86.1 \%$ & $92.9 \%$ & $95 \%$ & Valid \\
\hline Validator 3 & $94.4 \%$ & $96.4 \%$ & $100 \%$ & Valid \\
\hline Validator 4 & $97.2 \%$ & $94.6 \%$ & $90 \%$ & Valid \\
\hline Validator 5 & $91.7 \%$ & $92.9 \%$ & $80 \%$ & Valid \\
\hline Validator 6 & $77.8 \%$ & $76.8 \%$ & $92.5 \%$ & Valid \\
\hline Average & $90.7 \%$ & $92 \%$ & & \\
\hline
\end{tabular}

- Suitability Content

Potential Effectiveness

Overall Satisfaction
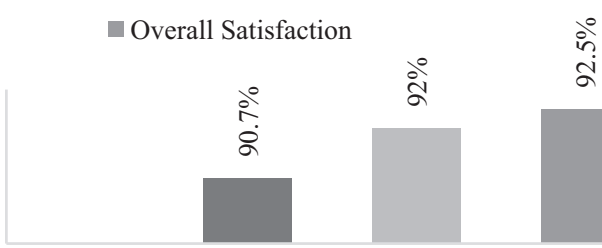

ì

$\stackrel{\circ}{\stackrel{2}{\circ}}$

AVERAGE OF VALIDATION PERCENTAGE

Fig. 4. Bar chart of average of validation

\subsection{Teachers' responses}

The valid module was given to chemistry teachers to investigate their response about the module in Table 9 shows the result of chemistry response to module.

Table 9. The result of chemistry teachers' response to module

\begin{tabular}{|l|c|l|}
\hline \multicolumn{1}{|c|}{ Items of Teachers' Response } & Percentage (\%) & Criteria Response of Users \\
\hline $\begin{array}{l}\text { This module can help my students to } \\
\text { understand chemistry easily }\end{array}$ & $91.67 \%$ & Very Good \\
\hline $\begin{array}{l}\text { The module can encourage my students' } \\
\text { science process skills }\end{array}$ & $90.74 \%$ & Very Good \\
\hline $\begin{array}{l}\text { The module can encourage my students to } \\
\text { know the chemical representation }\end{array}$ & $92.59 \%$ & Very Good \\
\hline $\begin{array}{l}\text { The module can make my teaching \& } \\
\text { learning be students-center }\end{array}$ & $94.44 \%$ & Very Good \\
\hline Average & $92.36 \%$ & Very Good \\
\hline
\end{tabular}

Based on Table 9, it is found that the chemistry teachers gave very good response to module. In detail, this module can help my students to understand chemistry easily (91.67\%), module can encourage my students' science process skills (90.74\%), module 
can encourage my students to know the chemical representation $(92.59 \%)$, and module can make my teaching \& learning be students-center (94.44\%). According to [38], if the result of percentage of teachers' response is around 75.00-100 the criteria response of teachers is very good. In this study, the average of percentage of teachers' response is $92.36 \%$, so the chemistry teachers show very good response to module. Therefore, this dual mode module can be used in learning chemistry because this module is student-centered approach so that it can encourage students to learn by doing and having new experience [42]. In addition, it also can be a solution for helping teachers' readiness in conducting learning and teaching. Because [42] stated that there were still many teachers who faced challenges in preparing lesson plan. Hence, this module is suitable for teacher to reduce the problem existed.

\section{Conclusion}

Dual mode module is developed to solve problem existed in learning chemistry especially on topic rate of reaction. This module integrated chemical representation and science process skills using Project Based Learning. Module developed is valid with suitability content is $90.7 \%$, potential effectiveness is $92 \%$, and overall satisfaction is $92.5 \%$. The chemistry teachers' response showed that this module is very good criteria $(92.36 \%)$. Due to the existence of problems in learning chemistry regarding the limitation of media that can be used in face to fac learning and online learning that can integrate science process skills and chemical representation, it makes this study need to be carried out. By developing dual mode module can be solution for overcoming these problems.

This study only focuses on developing module on topic rate of reaction, so it still needs further research to solve same problems on different chemistry topic. This limitation can be a gap for future research to create innovation to solve problems existed in learning chemistry to other chemistry topics.

\section{Acknowledgment}

The authors would like to thank Universiti Teknologi Malaysia (UTM) for their support in making this project possible. This work was supported by the Research University Grant (Q.J130000.2453.09G35 and Q.J130000.2409.04G91) initiated by UTM.

\section{$7 \quad$ References}

[1] Santosa, \& Siregar. (2017). Implementasi Kurikulum 2013 dalam Pembelajaran Kimia Kelas X SMA Se-Kota Jayapura. Jurnal Ilmu Pendidikan Indonesia, 5(2), 49-59. https:// doi.org/10.31957/jipi.v5i2.251

[2] Treagust, D., Chittleborough, G., \& Mamiala, T. (2003). The role of submicroscopic and symbolic representations in chemical explanations. International journal of science education, 25(11), 1353-1368. https://doi.org/10.1080/0950069032000070306 
[3] Tias, I. W. U., \& Octaviani, S. (2018). The Effect of Using Project Based Learning Model On (Quasi Study Experiments for Class V Students of SD Negeri 8 Metro Timur, SD Negeri 1 Metro Barat, SD Negeri 1 Metro Utara dan SD Negeri 5 Metro Pusat). Journal of Humanities and Social Studies, 02(02), 25-30.

[4] Santos, V. C., \& Arroio, A. (2016). The representational levels: Influences and contributions to research in chemical education. Journal of Turkish Science Education (TUSED), 13(1). https://doi.org/10.12973/tused.10153a

[5] Alharbi, B. (2021). 'Development of an ERP System Design Course to Improve Students' Learning Outcomes', International Journal of Emerging Technologies in Learning (iJET), 16(12), p. 276. doi: https://doi.org/10.3991/ijet.v16i12.22281

[6] Fouad Jawad, L., Kadhim Raheem, M., \& Hassan Majeed, B. (2021). 'The Effectiveness of Educational Pillars Based on Vygotsky's Theory in Achievement and Information Processing Among First Intermediate Class Students', International Journal of Emerging Technologies in Learning (iJET), 16(12), pp. 246-262. doi: https://doi.org/10.3991/ijet.v16i12.23181

[7] Lee, O., Eichinger, D. C., Anderson, C. W., Berkheimer, G. D., \& Blakeslee, T. D. (1993). Changing middle school students' conceptions of matter and molecules. Journal of Research in Science Teaching, 30(3), 249-270. https://doi.org/10.1002/tea.3660300304

[8] Sujak, K. B., Gnanamalar, E., \& Daniel, S. (2018). Understanding of Macroscopic, Microscopic and Symbolic Representations Among Form Four Students in Solving Stoichiometric Problems. MOJES: Malaysian Online Journal of Educational Sciences, 5(3), 83-96.

[9] Yasukhan, Supasorn, \& Wongkhan (2011).

[10] Rizal, M. (2014). Pengaruh Pembelajaran Inkuiri Terbimbing dengan Multi Representasi terhadap Keterampilan Proses Sains dan Penguasaan Konsep IPA Siswa SMP (The Influence of Guided Inquiry Learning with Multiple Representation of Process Skills of Science and Mastery of Science Concept of Junior High School Students). Jurnal Pendidikan Sains, 2(3), 159-165.

[11] Prastiwi, D., Lisdiana, H., \& Lisdiana. (2018). The Effectiveness of Guided Inquiry with Mind Mapping to Improve Science Process Skills and Learning Motivation Article Info. Journal of Primary Education JPE, 7(2), 195-203. https://journal.unnes.ac.id/sju/index. php/jpe/article/view/23535

[12] Susilaningsih, E., Supartono, S., Kristanto, T., Sariana, E., Azizah, P., \& Natasukma, M. (2019). The Effectiveness of Multiple Representation Oriented Learning Material with Project Based Learning to Improve Students' Chemistry Learning Outcomes. In 6th International Conference on Educational Research and Innovation (ICERI 2018) (pp. 359-362). Atlantis Press. https://doi.org/10.2991/iceri-18.2019.18

[13] Peng, J., Wang, M., Sampson, D., \& Van Merriënboer, J. J. G. (2019). Using a visualisationbased and progressive learning environment as a cognitive tool for learning computer programming. In Australasian Journal of Educational Technology (Issue 2). https://doi. org/10.14742/ajet.4676

[14] Balemen, N., \& Özer Keskin, M. (2018). The effectiveness of Project-Based Learning on science education: A meta-analysis search. International Online Journal of Education and Teaching (IOJET), 5(4), 849-865. http://iojet.org/index.php/IOJET/article/view/452/297

[15] Sumarni, W., Wardani, S., Sudarmin, S., \& Gupitasari, D. N. (2016). Project based learning (PBL) to improve psychomotor skills: A classroom action research. Jurnal Pendidikan IPA Indonesia, 5(2), 157-163. https://doi.org/10.15294/jpii.v5i2.4402

[16] Rose, R. A., \& Prasetya, A. T. (2015). Keefektifan strategi project based learning berbantuan modul pada hasil belajar kimia siswa. Jurnal Inovasi Pendidikan Kimia, 8(2).

[17] Sholahuddin, A., \& Shadriyah, Y. (2017). Analysis of Students' Process Skills and Chemistry Learning Outcomes. In 5th SEA-DR (South East Asia Development Research) International Conference 2017 (SEADRIC 2017) (pp. 364-370). Atlantis Press. https://doi.org/10.2991/ seadric-17.2017.79 
[18] Khatser, G. et al. (2021) 'Transformation of the Educational Process within Online Technologies Implementation in the Period of the Global Crisis', International Journal of Emerging Technologies in Learning (iJET), 16(11), p. 245. doi: https://doi.org/10.3991/ijet. v16i11.21265

[19] Sirhan, G. (2007). Learning Difficulties in Chemistry: An Overview. Journal of Turkish Science Education, 4(2), 2-20. http://www.tused.org

[20] Davidowitz, B., \& Chittleborough, G. (2009). Linking the Macroscopic and Sub-microscopic Levels: Diagrams. 169-191. https://doi.org/10.1007/978-1-4020-8872-8_9

[21] Penn, M., \& Ramnarain, U. (2019). South African university students' attitudes towards chemistry learning in a virtually simulated learning environment. Chemistry Education Research and Practice, 20(4), 699-709. https://doi.org/10.1039/C9RP00014C

[22] Taber, K. S. (2013). Revisiting the chemistry triplet: Drawing upon the nature of chemical knowledge and the psychology of learning to inform chemistry education. Chemistry Education Research and Practice, 14(2), 156-168. https://doi.org/10.1039/C3RP00012E

[23] Johnson, C. S., \& Delawsky, S. (2013). Project-Based Learning and Student Engagement, 4(4), 560-570.

[24] Martin, F., \& Bolliger, D. U. (2018). Engagement matters: Student perceptions on the importance of engagement strategies in the online learning environment. Online Learning Journal, 22(1), 205-222. https://doi.org/10.24059/olj.v22i1.1092

[25] Becker, N., Stanford, C., Towns, M., \& Cole, R. (2015). Translating across macroscopic, submicroscopic, and symbolic levels: The role of instructor facilitation in an inquiry-oriented physical chemistry class. Chemistry Education Research and Practice, 16(4), 769-785. https://doi.org/10.1039/C5RP00064E

[26] Johnstone, A. H. (1991). Why is science difficult to learn? Things are seldom what they seem. 7, 75-83. https://doi.org/10.1111/j.1365-2729.1991.tb00230.x

[27] Johnstone, A. H. (1993). Symposium on Fievolution and Evolution in Chemical Education: The Development of Chemistry Teaching. Journal of Chemical Education, 70(9), 701-705. https://doi.org/10.1021/ed070p701

[28] Johnstone, A. H. (2009). Multiple Representations in Chemical Education. In International Journal of Science Education, 31(16). https://doi.org/10.1080/09500690903211393

[29] Gkitzia, V., Salta, K., \& Tzougraki, C. (2020). Students' competence in translating between different types of chemical representations. Chemistry Education Research and Practice, 21(1), 307-330. https://doi.org/10.1039/C8RP00301G

[30] Safaah, E. S., Muslim, M., \& Liliawati, W. (2017). Teaching Science Process Skills by Using the 5-Stage Learning Cycle in Junior High School. Journal of Physics: Conference Series, 895(1). https://doi.org/10.1088/1742-6596/895/1/012106

[31] Rani, S. A., Wiyatmo, Y., \& Kustanto, H. (2017). Concept attainment worksheet to enhance concept knowledge and science process skills in physics instruction. Jurnal Pendidikan IPA Indonesia, 6(2), 326-334. https://doi.org/10.15294/jpii.v6i2.10520

[32] Nagarajan, S., \& Overton, T. (2019). Promoting Systems Thinking Using Project- and Problem-Based Learning. https://doi.org/10.1021/acs.jchemed.9b00358

[33] Islami, D., Adlim, M., \& Hasan, M. (2020). Project-based learning on water filtration experiment in high school chemistry subject. Journal of Physics: Conference Series, 1460(1). https://doi.org/10.1088/1742-6596/1460/1/012082

[34] Tegeh, I. M., I, N.J., \& Ketut, P. 2014. Model Penelitian Pengembangan. Yogyakarta: Graha Ilmu.

[35] Black, K. (2010). Business Statistics: Contemporary Decision Making (6th Edition). United States of America: John Wiley \& Sons. 
[36] Saraswati, L., \& Herdini. (2021). Development of Interactive E-Module Chemistry Magazine Based on Kvisoft Flipbook Maker for Thermochemistry Materials at Second Grade Senior High School. Journal of Science Learning.

[37] Septiani, D., \& Sumarni, D. (2014). Saptorini," The Effectiveness of Inquiry Learning Model with Module to Increase the Understanding of Concept and Generic Science Skills,". Jurnal Inovasi Pendidikan Kimia, 8(2), 1340-1350.

[38] Chee, K. N., Yahaya, N., \& Ibrahim, N. H. (2017). Effectiveness of mobile learning application in improving reading skills in Chinese language and towards post-attitudes. International Journal of Mobile Learning and Organisation, 11(3), 210-225. https://doi. org/10.1504/IJMLO.2017.085347; https://doi.org/10.1504/IJMLO.2017.10005992

[39] Ayriza, Y. (2008). Developing and validating the social life skill module for pre-school educators. Jurnal Penelitian dan Evaluasi Pendidikan, 12(2), 213-231.

[40] Dick, W., Carey, L., \& Carey, J. O. (2015). The Systematic Design of Instruction (8th ed.). Boston, USA: Pearson.

[41] Jamal, S. N. B., Ibrahim, N. H. B., \& Surif, J. B. (2019). Concept cartoon in problem-based learning: A systematic literature review analysis. Journal of Technology and Science Education, 9(1), 51-58. https://doi.org/10.3926/jotse.542

[42] Ramli, A. A., Ibrahim, N. H., Surif, J., Bunyamin, M. A. H., Jamaluddin, R., \& Abdullah, N. (2017). Teachers' readiness in teaching stem education. Man in India, 97(13), 343-350.

\section{Authors}

Wimbi Apriwanda Nursiwan is student of Master of Education (Chemistry), School of Education, Faculty Social Science and Humanities, Universiti Teknologi Malaysia, Johor Bahru, Malaysia, 81310. She received Bachelor of Education (Chemistry) from Universitas Riau, Indonesia and carried out research focusing on Diagnostic Test Based on Attribute Hierarchy Method (AHM), and now her research interest is about scientific creativity in chemistry education.

Mangai Solomon Mahanan is a postgraduate Master's student of chemistry Education at Universiti Teknologi Malaysia, Johor Bahru, Malaysia, 81310. His passion for science education has been from the foundation where he also obtained a Bachelor of Education in chemistry from the University of Jos. Mangai has been a chemistry teacher for over three years and has developed interest in Chemistry pedagogy and STEM education.

Nor Hasniza Ibrahim is senior lecturer in Department of Educ Science, Mathematics and Multimedia Creative, Faculty of Science Social and Humanities, Universiti Teknologi Malaysia, Johor Bahru, Malaysia, 81310. She received her Bachelor in Biomedical Sciences from Universiti Putra Malaysia, Master's Degree and Doctor of Philosophy in Chemistry Education from Universiti Teknologi Malaysia. Her research interest is regarding science education, chemistry education and STEM education. She now works as senior lecturer in She also currently actively involved in research and programs related to STEM education and indigenous people.

Johari Surif is associate professor in Department of Educ Science, Mathematics and Multimedia Creative, Faculty of Science Social and Humanities, Universiti Teknologi Malaysia, Johor Bahru, Malaysia, 81310. He received Bachelor in Environmental Sciences from Universiti Kebangsaan Malaysia, Master's Degree and Doctor of 
Philosophy in Chemistry Education from Universiti Teknologi Malaysia. His research interest is regarding science education, chemistry education and STEM education. He also currently actively involved in research and programs related to STEM education, community and many more.

Sharifah Osman is with Universiti Teknologi Malaysia, Johor Bahru, Malaysia.

Muhammad Abd Hadi Bunyamin is a senior lecturer at School of Education, Universiti Teknologi Malaysia (UTM). He obtained his Bachelor's and Master's degrees in Physics Education from UTM and PhD from the University of Minnesota, the United States. He has been doing research in STEM education especially physics teaching and learning and cultural studies in STEM in the settings of school and higher education. He currently involves in physics teaching and learning at a secondary school in Johor, Malaysia in a long-term professional development programme.

Article submitted 2021-06-04. Resubmitted 2021-07-14. Final acceptance 2021-07-15. Final version published as submitted by the authors. 